\title{
Ethanol Production during Semi-Continuous Syngas Fermentation in a Trickle Bed Reactor Using Clostridium ragsdalei
}

\author{
Mamatha Devarapalli ${ }^{1}$, Hasan K. Atiyeh ${ }^{1, *}$, John R. Phillips ${ }^{1}$, Randy S. Lewis ${ }^{2}$ and \\ Raymond L. Huhnke ${ }^{1}$ \\ 1 Biosystems and Agricultural Engineering Department, Oklahoma State University, \\ Stillwater, OK \\ ${ }^{2}$ Department of Chemical Engineering, Brigham Young University, Provo, UT \\ * Corresponding author. Associate Professor, Department of Biosystems and Agricultural \\ Engineering, 214 Ag Hall, Oklahoma State University, Stillwater, OK 74078, USA. \\ Tel.: +1.405.744.8397; Fax: +1.405.744.6059. Email address: hasan.atiyeh@ okstate.edu
}

\begin{abstract}
An efficient syngas fermentation bioreactor provides a mass transfer capability that matches the intrinsic kinetics of the microorganism to obtain high gas conversion efficiency and productivity. In this study, mass transfer and gas utilization efficiencies of a trickle bed reactor during syngas fermentation by Clostridium ragsdalei were evaluated at various gas and liquid flow rates. Fermentations were performed using a syngas mixture of $38 \% \mathrm{CO}$, $28.5 \% \mathrm{CO}_{2}, 28.5 \% \mathrm{H}_{2}$ and $5 \% \mathrm{~N}_{2}$, by volume. Results showed that increasing the gas flow rate from 2.3 to $4.6 \mathrm{sccm}$ increased the $\mathrm{CO}$ uptake rate by $76 \%$ and decreased the $\mathrm{H}_{2}$ uptake rate by $51 \%$ up to Run R6. Biofilm formation after R6 increased cells activity with over threefold increase in $\mathrm{H}_{2}$ uptake rate. At $1662 \mathrm{~h}$, the final ethanol and acetic acid concentrations were 5.7 and $12.3 \mathrm{~g} / \mathrm{L}$, respectively, at $200 \mathrm{ml} / \mathrm{min}$ of liquid flow rate and $4.6 \mathrm{sccm}$ gas flow rate.
\end{abstract}

Keywords: Semi-continuous syngas fermentation, Clostridium ragsdalei, Ethanol, Trickle 
bed reactor, mass transfer.

\section{Introduction}

Syngas fermentation is a biochemical conversion of synthesis gas (a mixture of CO, $\mathrm{H}_{2}$ and $\mathrm{CO}_{2}$ ) into various products such as alcohols and organic acids. Clostridium ljungdahlii, Clostridium carboxidivorans, Clostridium autoethanogenum, Alkalibaculum bacchi have been used in syngas fermentation (Abubackar et al., 2015; Liu et al., 2012; Phillips et al., 1994; Ukpong et al., 2012). These microorganisms undergo a set of enzyme catalyzed reactions through the Wood-Ljungdahl pathway to metabolize $\mathrm{CO}, \mathrm{H}_{2}$ and $\mathrm{CO}_{2}$ into cell mass, ethanol and acetic acid (Wood et al., 1986). Syngas fermentation has many advantages such as ambient fermentation temperature and pressure, flexibility of feedstocks (such as lignocellulosic and municipal solid wastes) and utilization of all the lignocellulosic biomass components including lignin. However, syngas fermentation suffers from low productivity associated with low cell density, enzyme inhibition and mass transfer limitations (Bredwell et al., 1999). The mass transfer limitation is a major challenge, which is attributed to the low solubility of $\mathrm{CO}$ and $\mathrm{H}_{2}$ in the fermentation medium.

Bioreactor designs such as continuously stirred tank reactors (CSTRs) with microspargers, packed columns, bubble columns, trickle beds and hollow fiber reactors have been employed to improve the mass transfer of gases into liquid medium (Bredwell et al., 1999; Klasson et al., 1991; Orgill et al., 2013; Shen et al., 2014; Vega et al., 1990). In a traditional CSTR, increasing the agitation speed and gas flow rate will increase the gasliquid mass transfer (Orgill et al., 2013). However, in commercial scale syngas fermentations, the high power to volume ratio requirements for large reactors may not be economical (Bredwell et al., 1999). Further, increasing the gas flow rate typically decreases 
the gas conversion efficiency if the amount of cells in the bioreactor is not sufficient to consume the gas provided. Unlike CSTRs, column reactors have no moving parts and thus have a low power requirement. In some fermentation studies, trickle bed reactors (TBR) were shown to have better mass transfer characteristics, productivity and gas conversions than packed bubble columns and CSTR (Cowger et al., 1992; Klasson et al., 1990b).

TBRs are long columns filled with packing material, which are widely used in chemical and biochemical processes when gas-liquid interactions occur in presence of a solid catalyst (Saroha and Nigam, 1996). The gas and liquid flow to the TBR can either be co-current or counter-current. The liquid trickles down the packing in the form of a thin film and reduces the resistance to gas-liquid mass transfer. TBRs were successfully used during syngas fermentations to produce (i) $\mathrm{H}_{2}$ using photosynthetic bacterium such as Rhodospirillum rubrum and Rubrivivax gelatinosus (Cowger et al., 1992); (ii) $\mathrm{CH}_{4}$ using tricultures of $R$. rubrum, Methanobacterium formicum and Methanosarcina barkeri (Kimmel et al., 1991; Klasson et al., 1990a) and (iii) acetate using Peptostreptococcus productus (Klasson et al., 1990b). However, based on extensive literature review no studies were reported on syngas fermentation using a TBR for alcohol production. The present research focuses on characterizing a 1-L TBR for ethanol production from syngas using Clostridium ragsdalei. Semi-continuous fermentations were performed in the TBR with 6mm glass beads. Further, the effect of gas and liquid flow rates on gas conversion efficiency, ethanol productivity and apparent mass transfer were evaluated.

\section{Materials and Methods}

\subsection{Microorganism and medium preparation}

Clostridium ragsdalei (ATCC-PTA-7826) a strict anaerobic bacterium was 
maintained and grown on a standard yeast extract medium that consisted mainly of $0.5 \mathrm{~g} / \mathrm{L}$ yeast extract (YE), $10 \mathrm{~g} / \mathrm{L}$ 2-(N-morpholino)ethanesulfonic acid (MES) buffer, $25 \mathrm{ml} / \mathrm{L}$ mineral solution without $\mathrm{NaCl}, 10 \mathrm{ml} / \mathrm{L}$ vitamin solution and $10 \mathrm{ml} / \mathrm{L}$ metal solution. The chemical components and their concentrations in the mineral, metal and vitamin solutions were previously reported (Maddipati et al., 2011). Also, $0.1 \%$ rezasurin as an $\mathrm{O}_{2}$ indicator and $10 \mathrm{ml} / \mathrm{L}$ of $4 \%$ (w/v) cysteine sulfide as a reducing agent were added. C. ragsdale $i$ was reported to tolerate $50 \mathrm{~g} / \mathrm{L}$ ethanol (Huhnke et. al. 2010).

\subsection{Inoculum preparation}

To reduce the lag phase, C. ragsdalei stock culture was passaged three times prior to inoculating the TBR. The inoculum was prepared in 250-ml serum bottles with $100 \mathrm{ml}$ of medium and $10 \%(\mathrm{v} / \mathrm{v})$ inoculum in each passage. The bottles were pressurized to $239 \mathrm{kPa}$ with $40 \% \mathrm{CO}, 30 \% \mathrm{CO}_{2}$ and $30 \% \mathrm{H}_{2}$ syngas mixture by volume. The cells were transferred from one passage to another after reaching cell optical density $\left(\mathrm{OD}_{660}\right)$ of about 0.5 . The third passage was used to inoculate the TBR. The culture took about 15-20 days to grow in the TBR with $10 \%(\mathrm{v} / \mathrm{v})$ inoculum in preliminary fermentations (data not shown). This was attributed to the high mass transfer in the TBR and high availability of $\mathrm{CO}$ to relatively low amount of cells during startup resulting in CO inhibition. Therefore, a 60\% (v/v) inoculum was used to inoculate the TBR. The increase in inoculum size and use of a low gas flow rate (2.3 standard cubic centimeters per minute ( $\mathrm{sccm}$ ), i.e., 0.005 volume of gas provided per volume of liquid per minute, vvm) started the fermentation in the TBR within $48 \mathrm{~h}$.

\subsection{TBR experimental setup}

Fig. 1 shows the schematic of the TBR used in syngas fermentation. The TBR was designed in-house and is made of borosilicate glass $(5.1 \mathrm{~cm}$ diameter by $61 \mathrm{~cm}$ length). For 
comparison purposes, the TBR design in the present study was similar to the TBR design reported by Wolfrum and Watt (2002). The 6-mm soda lime glass beads (VWR, Atlanta, GA, USA) were used as the packing material because they provided higher mass transfer $\left(k_{L} a / V_{L}\right)$ than the 3-mm beads during mass transfer studies (Orgill et al., 2013). A metal mesh with openings smaller than $3 \mathrm{~mm}$ was placed $9 \mathrm{~cm}$ from the bottom of the TBR to hold the glass beads in the reactor. A perforated circular liquid distributor with $3.2 \mathrm{~mm}$ holes was placed $11 \mathrm{~cm}$ below the reactor top. The liquid outlet line from the TBR was connected to a 500-ml Pyrex glass bottle as a sump to hold medium in excess of what was in the column and tubing. The TBR was initially operated in counter-current mode. To ensure no gas bypass from the bottom of the TBR liquid outlet to the sump headspace, the flexible tubing was restricted with a clamp to maintain a liquid seal at the TBR bottom. The $\mathrm{pH}$ and ORP probes (Cole-Parmer, Vernon, IL, USA) were placed inline in the recirculation loop before the peristaltic pump (Cole-Parmer), which was used to circulate the liquid at a desired flow rate. Liquid sample and acid/base addition ports were placed after the peristaltic pump. The TBR gas exit line was connected to a pressure gauge and to the sump gas inlet. A back pressure regulator connected to the sump gas exit line controlled the pressure in the TBR at $115 \mathrm{kPa}$. The gas exit line was further connected to a safety exhaust line with a pressure switch and a solenoid valve to vent excess pressure in the TBR. A bubbler was placed at the outlet of the pressure regulator to trap any product lost as a vapor with the exhaust stream. The amount of product recovered in the bubbler was very small (less than $10 \%$ of total product) due to a low gas flow rate.

\subsection{Experimental procedure}

The TBR column, sump and tubing were sterilized at $121^{\circ} \mathrm{C}$ for $20 \mathrm{~min}$. After 
sterilization, the TBR was purged with $\mathrm{N}_{2}$ for $6 \mathrm{~h}$ to establish anaerobic conditions. In the meanwhile, $200 \mathrm{ml}$ of fresh medium was prepared and transferred into a 500-ml serum bottle. The medium was then boiled and purged with $\mathrm{N}_{2}$ for about 3 to 5 min to remove $\mathrm{O}_{2}$ and sealed with an impermeable butyl rubber stopper and aluminum crimp seal. The medium was then sterilized in the autoclave. After sterilization, the bottle was pressurized to $239 \mathrm{kPa}$ with $\mathrm{N}_{2}$ so that the medium could be transferred by the pressure difference to the TBR. Sterile Teflon tubing with $22 \mathrm{G} 38-\mathrm{mm}$ needles on both ends was used to transfer the medium from the serum bottle into the TBR via the liquid sample port (Fig. 1).

After addition of $200 \mathrm{ml}$ of fresh medium into the TBR, the TBR was purged with $\mathrm{N}_{2}$ for at least $8 \mathrm{~h}$. Then, the inlet gas line to the TBR was switched to the syngas mixture of $38 \% \mathrm{CO}, 28.5 \% \mathrm{CO}_{2}, 28.5 \% \mathrm{H}_{2}$ and $5 \% \mathrm{~N}_{2}$ by volume (Stillwater Steel and Supply Company, Stillwater, OK, USA). This simulated gas mixture composition was similar to coal derived syngas (Klasson et al., 1993). An inoculum (300 ml) was added into the reactor through the liquid sample port in the same way as the $200 \mathrm{ml}$ of fresh medium. The total volume of the liquid medium and inoculum in the TBR and circulating loop was 500 ml. Temperature in the TBR column and sump was maintained at $37{ }^{\circ} \mathrm{C}$ using silicone heating tape and a surface thermocouple connected to a temperature controller (Omega $\mathrm{CN}$ 370 series, Stamford, CT, USA).

Gas and liquid samples were taken periodically for product analysis. For TBR startup, a $200 \mathrm{ml} / \mathrm{min}$ liquid flow rate and $2.3 \mathrm{sccm}$ gas flow rate were used. Preliminary experiments were performed to establish a startup procedure for the TBR (data not shown). It was found that medium replacement was important for semi-continuous fermentation to maintain cell activity and avoid nutrient limitations. Hence in the present study, multiple 
additions of fresh medium were used to maintain the cell metabolic activity and accumulate cell mass in the TBR. The cell mass in the TBR can be entrapped within the beads, form a biofilm or be suspended in the medium. In this paper, biofilm formation refers to all cell mass excluding suspended cells. After each run when the CO conversion efficiency dropped to between 35 and 40\%, $400 \mathrm{ml}$ of spent medium in the TBR was removed from the sample port and replaced with $400 \mathrm{ml}$ of fresh medium. Two gas (2.3 and $4.6 \mathrm{sccm})$ and three liquid flow rates $(200,500$ and $700 \mathrm{ml} / \mathrm{min}$ ) were tested. Runs R1 and R2 were performed at liquid and gas flow rates of $200 \mathrm{ml} / \mathrm{min}$ and $2.3 \mathrm{sccm}$, respectively. Runs R3 to R10, R12 and R19 were performed at liquid and gas flow rates of $200 \mathrm{ml} / \mathrm{min}$ and 4.6 sccm, respectively. For runs R11, R13 and R17, the liquid and gas flow rates were 500 $\mathrm{ml} / \mathrm{min} 4.6 \mathrm{sccm}$, respectively. Runs R14, R15 and R18 were performed at liquid and gas flow rates of $700 \mathrm{ml} / \mathrm{min}$ and $4.6 \mathrm{sccm}$, respectively. Run R16 had leak issues, which resulted in no data. Runs R1 to R15 were performed in counter-current mode. Runs R17 to R19 were in co-current flow mode. The switch to co-current mode was done to avoid the operational difficulties with gas bypass and foam formation at high liquid recirculation rates (500 and $700 \mathrm{ml} / \mathrm{min}$ ) during counter-current operation. The gas flow rate was set constant at $4.6 \mathrm{sccm}$ in runs R17 to R19 while the liquid flow rate was maintained at 500 $\mathrm{ml} / \mathrm{min}, 700 \mathrm{ml} / \mathrm{min}$ and $200 \mathrm{ml} / \mathrm{min}$ for runs $\mathrm{R} 17, \mathrm{R} 18, \mathrm{R} 19$, respectively.

\subsection{Analytical methods}

\subsubsection{Cell optical density measurement}

The cell optical density (OD) in the medium was measured at $660 \mathrm{~nm}$ using a UV spectrophotometer (Cole Parmer). At the end of run R19, the total cell OD in the medium and attached to the beads in the TBR was measured. The beads were collected in a clean 
tub and washed four times each with $500 \mathrm{ml}$ of DI water. No cells were found on the washed beads when the beads were examined using SEM, which indicates cells were loosely attached to the beads. Duplicate liquid samples were collected from each wash and measured at $660 \mathrm{~nm}$. The TBR wall was also washed to measure the concentration of cells attached to the wall. The sum of cell concentrations from the washes and the TBR wall provided the total cell mass as optical density in the reactive volume between the beads.

\subsubsection{Solvent analysis}

Ethanol and acetic acid concentration in the liquid samples were analyzed using DB-FFAP capillary column gas chromatography (GC) with flame ionization detector (FID) (Agilent Technologies, Wilmington, DE, USA). $\mathrm{H}_{2}$ was used as carrier gas with an initial flow rate of $2.3 \mathrm{ml} / \mathrm{min}$ for $1.5 \mathrm{~min} . \mathrm{H}_{2}$ flow was then ramped at $1 \mathrm{ml} / \mathrm{min}^{2}$ until the flow reached $4 \mathrm{ml} / \mathrm{min}$. The inlet port temperature was set at $200{ }^{\circ} \mathrm{C}$ with a split ratio of 50:1. The FID was set at $250{ }^{\circ} \mathrm{C}$ with $\mathrm{H}_{2}$ and air flow rates of $40 \mathrm{ml} / \mathrm{min}$ and $450 \mathrm{ml} / \mathrm{min}$, respectively. The initial oven temperature was $40{ }^{\circ} \mathrm{C}$ with a holding time of $1.5 \mathrm{~min}$. Then the temperature was ramped at $25^{\circ} \mathrm{C} / \mathrm{min}$ until reaching $60^{\circ} \mathrm{C}$. Following the initial ramping, the temperature was increased from $60{ }^{\circ} \mathrm{C}$ to $235^{\circ} \mathrm{C}$ at a rate of $40{ }^{\circ} \mathrm{C} / \mathrm{min}$.

\subsubsection{Gas analysis}

The gas samples were analyzed using a Carboxen 1010 PLOT capillary column (Supelco, Bellefonte, PA, USA) in a $6890 \mathrm{~N}$ GC with a thermal conductivity detector (TCD) (Agilent Technologies). A 100- $\mu$ l gas sample was injected using a Hamilton gas tight syringe (Hamilton Co., Reno, NV, USA). Argon was used as the carrier gas with an initial flow rate of $2 \mathrm{ml} / \mathrm{min}$ for $3.5 \mathrm{~min}$, and then it increased to $2.5 \mathrm{ml} / \mathrm{min}$ at a ramping rate of $0.1 \mathrm{ml} / \mathrm{min}^{2}$. The inlet port temperature was set at $200{ }^{\circ} \mathrm{C}$ with a $30: 1$ split ratio and the 
TCD temperature was set at $230{ }^{\circ} \mathrm{C}$. The oven temperature was set to $80{ }^{\circ} \mathrm{C}$ for $3.5 \mathrm{~min}$, then it was ramped to $235^{\circ} \mathrm{C}$ at $40^{\circ} \mathrm{C} / \mathrm{min}$. The gas and liquid data analysis was done using Chemstation software (Agilent Technologies).

\subsection{4 pH and ORP measurements}

The readings from the inline $\mathrm{pH}$ probe (Fig. 1) connected to the Bioflo 110 controller (New Brunswick Scientific Co., Edison, NJ, USA) were logged into the computer using Biocommand software (New Brunswick Scientific Co.). The ORP measurements were recorded periodically from a digital ORP meter (Omega).

\section{Results and Discussion}

\subsection{Cell growth and pH}

The cell optical density $\left(\mathrm{OD}_{660}\right)$ profiles for selected fermentation runs are shown in Fig. 2. Selected fermentation runs (13 out of 19 runs) were shown for ease of comparison when operating conditions were changed. The cell $\mathrm{OD}_{660}$ in the medium in run $\mathrm{R} 1$ reached a maximum of 0.5 and then likely decreased because of nutrient depletion since replacing the depleted medium with fresh medium resumed growth and increased the cell $\mathrm{OD}_{660}$ in run $\mathrm{R} 2$. However, the cell $\mathrm{OD}_{660}$ dropped again due to nutrient limitation. This trend was similar for all fermentation runs. It can be observed that irrespective of the final cell $\mathrm{OD}_{660}$

in the previous run, the initial measured suspended cell $\mathrm{OD}_{660}$ in the medium was about the same from R7 to R15 (Fig. 2). This possibly indicates resuspension of cells from biofilm into the medium after medium replacement and starting liquid recirculation. The retained cell broth from the previous run was $100 \mathrm{ml}$ (from the total $500 \mathrm{ml}$ in the system), which represents a $20 \%$ "inoculum" for the next run without consideration of the cells trapped in the packing. A maximum cell $\mathrm{OD}_{660}$ of 0.24 was measured in the medium between 1307 
and $1734 \mathrm{~h}$ in the co-current flow operation in runs R17 to R19. The cell $\mathrm{OD}_{660}$ dropped to 0.02 from 1573 to $1662 \mathrm{~h}$ in run R19. The highest cell $\mathrm{OD}_{660}$ in runs R3 to R19 decreased (Fig. 2) during each subsequent run likely due to biofilm formation in the reactive volume of the TBR. For the first $336 \mathrm{~h}$ of fermentation, the maximum suspended cell $\mathrm{OD}_{660}$ in the liquid medium of 0.65 was measured in run R3. Further, from 336 to 826 h, the highest cell $\mathrm{OD}_{660}$ in the liquid medium decreased from 0.53 in run $\mathrm{R} 4$ to 0.30 in run R10. Regardless of the decrease in the cell $\mathrm{OD}_{660}$ in the medium (Fig. 2), $\mathrm{CO}$ and $\mathrm{H}_{2}$ gas conversions efficiencies between $65 \%$ and $81 \%$ and between $18 \%$ to $41 \%$, respectively, (Fig. 4) were measured for runs R3 to R10 indicating high amount of cells held in the packing.

At the end of fermentation run R19, the beads were collected in a tub and washed four times with $500 \mathrm{ml} \mathrm{DI}$ water. The cell $\mathrm{OD}_{660}$ of the wash 1, wash 2, wash 3 and wash 4 were $1.91,0.54,0.13$, and 0.052 , respectively. A cell $\mathrm{OD}_{660}$ of 0.097 was obtained in the $500 \mathrm{ml}$ of DI water used to wash the column. The overall cell $\mathrm{OD}_{660}$ in the TBR after 1662 h (R19) was calculated to be 2.59 based on $500 \mathrm{ml}$ medium. This high $\mathrm{OD}_{660}$ indicates some degree of biofilm formation on the packing. It should be noted that biofilm formation was not reported in any earlier syngas fermentation studies in a TBR, which were focused on the production of $\mathrm{H}_{2}, \mathrm{CH}_{4}$ and acetate by photosynthetic and methanogenic bacteria (Kimmel et al., 1991; Klasson et al., 1990a; Klasson et al., 1993; Wolfrum and Watt, 2002).

Based on the measured concentrations of suspended cell mass in the medium, the specific cellular growth rate in the circulating medium was between 0.02 to $0.09 \mathrm{~h}^{-1}$ for all runs. However, it is difficult to accurately measure the specific growth rates in each run due to entrapment of cells between the beads. The specific growth rate during syngas fermentation by $C$. ragsdalei in yeast extract medium with $1 \mathrm{~g} / \mathrm{L}$ YE in batch bottles and 
CSTR was reported to be $0.06 \mathrm{~h}^{-1}$ (Maddipati et al., 2011). Thus, the specific growth rates obtained in the TBR for runs R1 to R10 were comparable to this reported value.

The initial $\mathrm{pH}$ of the medium in each run was about 5.8. The $\mathrm{pH}$ of the medium dropped to about 4.6 during fermentation due to acetic acid production. In initial fermentation runs ( $\mathrm{R} 1$ and $\mathrm{R} 2$ ) at a gas flow rate of $2.3 \mathrm{sccm}$ and liquid recirculation rate of $200 \mathrm{ml} / \mathrm{min}$, it took $106 \mathrm{~h}$ for the $\mathrm{pH}$ to drop from 5.8 to 4.6. However, at a gas flow rate of $4.6 \mathrm{sccm}$ and liquid flow rate of $200 \mathrm{ml} / \mathrm{min}$, the $\mathrm{pH}$ dropped from 5.8 to 4.6 in 89 and $47 \mathrm{~h}$ in $\mathrm{R} 3$ and $\mathrm{R} 4$, respectively. In subsequent runs, the $\mathrm{pH}$ decreased from 5.8 to 4.6 in about $39 \mathrm{~h}$ irrespective of the operating conditions. The quick drop in $\mathrm{pH}$ in subsequent runs was likely attributed to the increase in the production rate of acetic acid (Fig. 5).

\subsection{Product profiles}

The ethanol and acetic acid concentrations showed a nearly-liner increasing trend in all fermentation runs (Fig. 3), implying a constant productivity of both ethanol and acetic acid. Because the fermentation time was not the same in all the runs, the comparison between runs was made at $60 \pm 4 \mathrm{~h}$ (see Table 1) after the start of each run since all runs occurred for at least this amount of time. In runs R1 and R2 with a liquid recirculation rate of $200 \mathrm{ml} / \mathrm{min}$ and a gas flow rate of $2.3 \mathrm{sccm}$, the average amounts of ethanol and acetic acid produced during the first $60 \pm 4 \mathrm{~h}$ were $1.19 \pm 0.04$ and $3.78 \pm 0.4 \mathrm{~g} / \mathrm{L}$, respectively (Table 1). In R3 and R4, doubling the gas flow rate resulted in a 75\% increase in ethanol production and only a $6 \%$ increase in acetic acid concentration.

The average amounts of ethanol and acetic acid produced during the first $60 \pm 4 \mathrm{~h}$ in runs R3 to R10 were $1.49 \pm 0.45$ and $4.75 \pm 0.81 \mathrm{~g} / \mathrm{L}$, respectively. While, there was no statistical significant increase in ethanol produced during R3 to R10 ( $p>0.1)$ compared to 
$\mathrm{R} 1$ and R2 there was a significant increase in acetic acid produced during R3 to R10 ( $<<$ 0.1). This increase in the acetic acid produced from R 3 to R 10 was likely due to supplying more syngas at double the rate leading to possibly more biofilm formation in the TBR. Liu et al. (2014a) reported that accumulation of high cell concentration during syngas fermentation in the bioreactor favored acetic acid production associated with ATP generation because more energy was required for cell maintenance. Comparing runs R3 and R4 with R5 through R10, which were operated at the same conditions, the decrease in ethanol production and the increase in acetic acid production indicates more cell growth during these latter runs. Such growth was likely due to an increase in biofilm formation since more growth in freely suspended cells in the medium was not evident (Fig. 2).

At the end of R10, it was assumed that the TBR was operating at quasi-steady state when only slight changes in gas conversion efficiencies and product concentrations were measured (see Table 1 and Fig. 3). At this point, the liquid recirculation rate was changed to $500 \mathrm{ml} / \mathrm{min}$ (R11 and R13) and $700 \mathrm{ml} / \mathrm{min}$ (R14 and R15) to examine the effect of liquid recirculation rate on fermentation. In comparison to R10, the variations in amounts of ethanol and acetic acid produced at different liquid flow rates were only between 4 to $20 \%$. This shows that the liquid recirculation flow rate had slight effect on ethanol and acetic acid produced. At these low gas flow rates and high liquid flow rates the gas-liquid interaction in the TBR was in the bubble flow regime (Ranade et al., 2011).

During counter-current operation at the liquid and gas flow rates shown in Table 1 (R1-R15) and by visual inspection, it appeared that the TBR was operating in the bubble flow regime (i.e., continuous liquid phase and gas flows as bubbles). Therefore, the gasliquid interfacial area, which affects the gas-liquid mass transfer, should be a function of 
the gas flow rate not the liquid flow rate. In general, up to 98 and $83 \%$ more ethanol and acetic acid, respectively, were produced in co-current mode than in counter-current mode.

Overall, syngas fermentation in the TBR with co-current mode was easier to operate and produced more ethanol and acetic acid than in counter-current mode. Unlike countercurrent flow, the capacity of co-current operation is not limited by flooding over a wider range of gas and liquid flow rates (Bredwell et al., 1999; Klasson et al., 1992). Better gas liquid interaction and no operational hindrances such as gas bypass, flooding and foaming were attributed to higher ethanol and acetic acid production in co-current mode. The final ethanol and acetic acid concentrations in the TBR with co-current flow at $1662 \mathrm{~h}$ were 5.7 and $12.3 \mathrm{~g} / \mathrm{L}$ (Fig. 3), respectively. There is no report on C. ragsdalei tolerance level of acetic acid. However, with a final acetic acid concentration of $12.3 \mathrm{~g} / \mathrm{L}$ produced by $C$. ragsdale $i$ at $\mathrm{pH} 4.7$, the undissociated acetic acid concentration was about $6.8 \mathrm{~g} / \mathrm{L}$ (113 $\mathrm{mM}$ ) as estimated by Henderson-Hasselbalch Equation (Po and Senozan, 2001). This is over twofold higher than undissociated acetic acid concentration of $3 \mathrm{~g} / \mathrm{L}(50 \mathrm{mM})$ that was reported to severely inhibit growth of $C$. coskatii, another syngas fermenting microorganism (Zahn and Saxena, 2014).

In the semi-continuous fermentations, nutrients were replenished in each new run when the CO conversion efficiency dropped between 35 and 40\%. Replenishing nutrients resulted in conditions that favored cell growth and biofilm formation in the TBR. The amounts of acetic acid and ethanol produced during semi-continuous syngas fermentations (only continuous gas flow) in various reactors are compared in Table 2 . The semicontinuous syngas fermentations were performed with either pure or mixed cultures. The amounts of products depend on the microorganism, medium composition, operating 
conditions and reactor type used. Although comparisons shown in Table 2 are difficult since final concentrations rather than production rates are shown, the information can still give some insights into the various reactor designs. The final acetic acid titer in the TBR with co-current mode in the present study was higher than in the STR and hollow fiber membrane reactor (HFR). However, acetic acid produced in the TBR with counter-current mode was lower than in the HFR. Ethanol produced in the TBR with $C$. ragsdalei was higher than in STR using C. ljungdahlii, C. autoethanogenum, C. carboxidivorans, A. bacchi and mixed culture strains (Abubackar et al., 2015; Cotter et al., 2009; Liu et al., 2014b; Singla et al., 2014; Ukpong et al., 2012). C. ragsdalei also produced slightly more ethanol in the TBR with co-current mode than in the STR using YE medium (Maddipati et al., 2011). Ethanol titers of 9.6 and $15 \mathrm{~g} / \mathrm{L}$ were also reported in STR with corn steep liquor medium (Maddipati et al., 2011) and in HFR with YE medium (Shen et al., 2014).

\subsection{Gas conversions}

The $\mathrm{CO}$ and $\mathrm{H}_{2}$ conversion efficiencies in the TBR for all runs, defined as the amount utilized divided by the amount flowing into the TBR, are shown in Fig. 4. The CO conversion efficiency increased in run R1, reached a maximum of $91 \%$ and then decreased. This was likely due to reduced cell activity with nutrient limitation since replacing the medium in $\mathrm{R} 2$ resulted in an increase in $\mathrm{CO}$ conversion efficiency. However, the same pattern of a reduction in the conversion efficiency occurred again due to nutrient limitation. This trend was similar for both $\mathrm{CO}$ and $\mathrm{H}_{2}$ conversion efficiencies for all runs (Fig. 4). The initial runs (R1 and R2) with a liquid recirculation rate of $200 \mathrm{ml} / \mathrm{min}$ and a gas flow rate of $2.3 \mathrm{sccm}$ achieved maximum conversion efficiencies of $91 \%$ for $\mathrm{CO}$ and $68 \%$ for $\mathrm{H}_{2}($ Table 1). However, when the gas flow rate was doubled to $4.6 \mathrm{sccm}$, the maximum $\mathrm{CO}$ and $\mathrm{H}_{2}$ 
conversion efficiencies in runs $\mathrm{R} 3$ to $\mathrm{R} 6$ decreased to 66 and 20\%, respectively. $\mathrm{CO}$ and $\mathrm{H}_{2}$ conversion efficiencies in runs R7-R10 and R12 increased with maximum $\mathrm{CO}$ and $\mathrm{H}_{2}$ conversion efficiencies of 81 and $47 \%$ achieved in R9 and R12, respectively. There was sustained increase in the maximum $\mathrm{H}_{2}$ conversion for runs $\mathrm{R} 3$ to $\mathrm{R} 10$, which was likely due to biofilm formation. As the biofilm formation establishes, the cell's kinetic capacity increases due to the increase of the cell mass in the TBR. The lower $\mathrm{H}_{2}$ conversion efficiencies compared to $\mathrm{CO}$ is likely due to $\mathrm{CO}$ inhibition of hydrogenase. The hydrogenase activity of C. ragsdalei was reduced by $90 \%$ when the CO partial pressure was $8.5 \mathrm{kPa}$ (Skidmore, 2010). In the present study, the partial pressure of $\mathrm{CO}$ at the inlet of the TBR was $43.2 \mathrm{kPa}$. The decrease in hydrogenase activity decreases $\mathrm{H}_{2}$ utilization. In the present study, $\mathrm{H}_{2}$ was simultaneously utilized with $\mathrm{CO}$ but at a lower rate (Fig. 5A). However, a greater amount of $\mathrm{H}_{2}$ can be utilized after $\mathrm{CO}$ has been depleted during syngas fermentation with C. ljungdahlii (Younesi et al., 2005).

The high concentration of $\mathrm{CO}$ and low cell mass in the TBR in the initial runs inhibited $\mathrm{H}_{2}$ uptake and resulted in low $\mathrm{H}_{2}$ conversion efficiency (Table 1). However, as the cell mass concentration in the TBR increased, $\mathrm{H}_{2}$ conversion efficiency increased due to higher amount of cells. In addition, the inhibition effect of $\mathrm{CO}$ on hydrogenase decreases in the TBR because CO is consumed by cells as it flows through the TBR packing. However, although it is difficult to assess, the cells near the TBR entrance are more likely to have $\mathrm{H}_{2}$ inhibition due to a higher exposure to $\mathrm{CO}$. In the counter-current mode, cells consume $\mathrm{CO}$ as the syngas flows from the bottom to the top of the TBR. This causes CO concentrations to drop along the length of the TBR and reduces its inhibition on hydrogenase. This effect with the increase in cell concentration in the packing material resulted in an increase in the 
$\mathrm{H}_{2}$ conversion efficiency and $\mathrm{H}_{2}$ uptake rate in $\mathrm{R} 3$ to $\mathrm{R} 15$ (Table 1 and Fig. 5A). The $\mathrm{H}_{2}$ uptake rate was similar for runs $\mathrm{R} 9$ to $\mathrm{R} 10$, indicating that biofilm formation reached a quasi-steady state. This phenomenon of increase in $\mathrm{H}_{2}$ conversion due to possible biofilm formation was not discussed in the literature because no biofilm formation was reported in earlier TBR syngas fermentation studies (Kimmel et al., 1991; Klasson et al., 1993; Wolfrum and Watt, 2002).

After the TBR reached quasi-steady state, the liquid circulation rate was changed in runs $\mathrm{R} 10$ to $\mathrm{R} 15$ (Table 1). The variations in the maximum $\mathrm{CO}$ and $\mathrm{H}_{2}$ conversion efficiencies at different liquid flow rate were within $15 \%$ of each other. Additionally, in the co-current mode from runs $\mathrm{R} 17$ to $\mathrm{R} 19$, the variations in the maximum $\mathrm{CO}$ and $\mathrm{H}_{2}$ conversion efficiencies at different liquid flow rates were within $10 \%$ of each other (Table 1). This indicates that the liquid flow rate had a small effect on the $\mathrm{CO}$ and $\mathrm{H}_{2}$ conversion efficiencies in the counter-current and co-current modes. A two-tailed t-test with unequal variances was performed and it was observed that there was no significant difference between $\mathrm{CO}$ and $\mathrm{H}_{2}$ gas conversions at the three examined liquid flow rates $(\mathrm{p}>0.1)$.

\subsection{Rates of gas uptake and product formation}

$\mathrm{CO}$ and $\mathrm{H}_{2}$ uptake rates are shown in Fig. 5A, which were estimated from the linear slope of the cumulative gas consumed (in mmol) between $10 \pm 5 \mathrm{~h}$ and $60 \pm 4 \mathrm{~h}$ of fermentation for each run. The linear slopes (not shown) suggest that the consumption rate was constant throughout the run. The averages $\mathrm{CO}$ and $\mathrm{H}_{2}$ uptake rate by $C$. ragsdalei for runs R1 and R2 were 2.12 and $0.92 \mathrm{mmol} / \mathrm{h}$, respectively. In R3, when the gas flow rate was increased to $4.6 \mathrm{sccm}$, the rate of $\mathrm{CO}$ uptake increased by $26 \%$ and rate of $\mathrm{H}_{2}$ uptake decreased by $46 \%$. In the subsequent runs (from R4 to R9) at the same operating 
conditions, the rate of $\mathrm{CO}$ uptake increased further by $24 \%$ in $\mathrm{R} 4$ and $35 \%$ in $\mathrm{R} 9$ compared to R3. However, the rate of $\mathrm{H}_{2}$ uptake increased by $8 \%$ in $\mathrm{R} 4$ and $184 \%$ in $\mathrm{R} 9$ compared to R3. The increase in $\mathrm{CO}$ and $\mathrm{H}_{2}$ uptake rates in the subsequent runs is an indication of an increase in the amount of cells in the TBR. It can also be observed from Fig. 5A that CO uptake rate was generally similar in runs R4 to R19. However, there was a steady increase in $\mathrm{H}_{2}$ uptake rate in runs $\mathrm{R} 4$ to $\mathrm{R} 8$ followed by a similar uptake rates in $\mathrm{R} 9$ and $\mathrm{R} 10$. Biofilm formation was considered to be established under quasi-steady state conditions when the variation in $\mathrm{CO}$ and $\mathrm{H}_{2}$ uptake rates were below $10 \%$ in run $\mathrm{R} 10$ compared to $\mathrm{R} 9$. The higher $\mathrm{CO}$ uptake rates compared to $\mathrm{H}_{2}$ uptake rates is consistent with thermodynamic analysis that showed that electron production from $\mathrm{CO}$ is more favorable than from $\mathrm{H}_{2}$ independent of $\mathrm{pH}$ and gas partial pressure (Hu et al., 2011). It is also difficult to estimate the amounts of $\mathrm{CO}$ and $\mathrm{H}_{2}$ that were used for either cell synthesis or product formation.

Ethanol and acetic acid formation rates (Fig. 5B) were calculated from the linear slope of the ethanol and acetic acid concentration profiles in the first $60 \pm 4 \mathrm{~h}$ of fermentation (Fig. 3). In runs R1 and R2, the average ethanol and acetic acid production rates were 0.38 and $0.68 \mathrm{mmol} / \mathrm{L} \cdot \mathrm{h}$, respectively. When the gas flow rate was doubled, ethanol production rate increased by $81 \%$ in R3 and R4 compared to R2. The acetic acid production rate increased by $60 \%$ in $\mathrm{R} 3$ and more than doubled in $\mathrm{R} 4$ compared to $\mathrm{R} 2$. The ethanol production rate decreased by $15 \%$ in run $\mathrm{R} 5$ and $51 \%$ in run R9 compared to R4. The increase in the amount of cells in the packing at constant gas flow shifted the production from ethanol to acetic acid. While the acetic acid production rate slightly increased up to $11 \%$ in runs R5 to R9 compared to R4. Ethanol production rates (Fig. 5B) decreased in runs R3 to R10 at the same operating conditions (Table 1). However, acetic 
acid production rate slightly increased and remained stable in runs R3 to R10. The decrease in the ethanol production rate was attributed to the increase in cell maintenance due to biofilm formation. When the liquid recirculation rates were varied in runs R10 to R15, small changes in ethanol and acetic acid production rates were observed. However, higher ethanol and acetic acid production rates were obtained in the co-current mode in runs R17 to R19 indicating a better gas-liquid interaction. In addition, there was no clear correlation between gas uptake rate and product formation rate (Fig. 5).

\subsection{Product yields}

Ethanol and acetic acid yields (Table 1) were calculated based on CO consumed as per equations previously reported in Liu et al. (2012). Net ethanol and acetic acid produced in each run was considered in the estimation of the yields. It is assumed that Based on stoichiometry, one mole of ethanol is produced from six moles of $\mathrm{CO}$ and one mole of acetic acid is produced from four moles of CO. Although yields above $100 \%$ are feasible when $\mathrm{H}_{2}$ is utilized (which it was for this study), yields based on $\mathrm{CO}$ utilization alone can still provide comparative insights. The average ethanol and acetic acid yields for R1 and R2 were $59.8 \%$ and $74.8 \%$, respectively (Table 1 ). When the gas flow rate was doubled from 2.3 to $4.6 \mathrm{sccm}$ in run $\mathrm{R} 3$, the ethanol yield increased to $91.6 \%$ and acetic acid yield was at $61.8 \%$. However, ethanol yield decreased by $27 \%$ and acetic acid yield increased by $54 \%$ in runs R4 to R6. As fermentation progressed in runs R7 to R10, more of the gas consumed was used for assimilation of cell biomass and maintenance resulting in a decrease in ethanol yield. After run R10, the variations in ethanol and acetic acid yields at different liquid recirculation rates were below $20 \%$. Further, a two-tailed t-test with unequal variances was performed and it was observed that there was no significant difference between ethanol and 
acetic acid yields at the three examined liquid flow rates $(\mathrm{p}>0.1)$. The ethanol and acetic acid yields in the TBR with co-current mode in runs R18 and R19 were higher than in counter-current operation for runs R10 to R15 (Table 1).

Reductant balance was estimated at the end of each run using Eq. 1, as the ratio of total reductants in products (ethanol and acetic acid) formed divided by total reductants ( $\mathrm{CO}$ and $\mathrm{H}_{2}$ ) consumed. Based on stoichiometry, 6 reductants and 4 reductants are required for production of ethanol and acetic acid, respectively.

$$
\text { Reductant balance }=\frac{6 \cdot n_{E t O H}+4 \cdot n_{A A}}{n_{C O}+n_{H_{2}}}
$$

where $n_{E t O H}$ and $n_{A A}$ are total moles of ethanol and acetic acid produced, respectively; $n_{C O}$ and $n_{H 2}$ are total moles of $\mathrm{CO}$ and $\mathrm{H}_{2}$ consumed. The reductant balance closed to within $10 \%$ for runs R4 to R6 and R17 to R19, and closed to within $20 \%$ for runs R1 to R3 and R7, R8 and R11. However, reductant balance closed to within $35 \%$ for runs R9, R10 and R13 to R15. For run R12, the reductant balance closed to within $47 \%$. The difficulty to close the reductant balance to 1.0 was due to gas bypass and flooding issues encountered in the TBR especially at high liquid recirculation rates during counter-current operation.

\subsection{Mass transfer analysis}

When mass transfer limiting conditions exist during fermentation, the concentration of the limiting gas reactant in the liquid approaches zero. Under such limitations, the apparent mass transfer coefficients $k_{L, C O} a / V_{L}$ and $k_{L, H 2} a / V_{L}$ at any time can be calculated using the equation reported in the literature (Sherwood et al., 1975): 


$$
\frac{k_{L, i} \cdot a}{V_{L}}=\frac{\left(-\frac{1}{V_{L}} \cdot \frac{d n_{i}}{d t}\right)}{\left[\frac{C_{\text {out }, i}-C_{i n, i}}{\ln \left(C_{\text {out }, i} / C_{i n, i}\right)}\right]}
$$

where $d n_{i} / d t$ is the instantaneous molar rate of gas component $i$ transferred into the medium $(\mathrm{mmol} / \mathrm{h}), V_{L}$ is the dynamic liquid holdup volume in the TBR (L), $k_{L, i} a / V_{L}$ is the volumetric mass transfer coefficient of gas $\left(\mathrm{h}^{-1}\right)$ and $i$ represents either $\mathrm{CO}$ or $\mathrm{H}_{2}, C_{i n, i}$ is the liquid phase concentration of gas reactant $i$ in equilibrium by Henry's Law with the gas at the TBR inlet (mmol/L) based on the gas cylinder composition and $C_{\text {out }, i}$ is the liquid phase concentration of gas reactant $i$ in equilibrium by Henry's Law with the gas at the TBR exit (mmol/L), which was measured by the GC. Eq. 2 assumes the limiting gas behaves as plug flow along the column length and decreases from the inlet to the outlet. Additionally, the driving force in Eq. 2 is based on the logarithmic average value between the inlet and outlet gas streams (Garcia-Ochoa and Gomez, 2009).

Eq. 2 would give a minimum $k_{L, i} a / V_{L}$ (denoted as apparent $\left.k_{L, i} a / V_{L}\right)$ since removal of the zero liquid concentration would result in a higher calculated $k_{L, i} a / V_{L}$. The apparent $k_{L, i} a / V_{L}$ as a function of time was calculated for $\mathrm{CO}$ and $\mathrm{H}_{2}$ since either of these gases could be limiting under varying circumstances.

The apparent $k_{L, C O} a / V_{L}$ and $k_{L, H 2} a / V_{L}$ in each run increased with increase in the gas uptake, reached a maximum and then started to decrease due to decrease in the cell activity as the nutrients were depleted in the medium (Fig. 6). The fermentation transitions from a kinetic limit for gas uptake due to low cell amount in the packing, to a mass transfer limit particularly for $\mathrm{CO}$, to a kinetic limit due to depleted nutrients. This trend was similar in all 
the fermentation runs R1 to R19. The maximum apparent $k_{L, C O} a / V_{L}$ and $k_{L, H 2} a / V_{L}$ were 544 $\mathrm{h}^{-1}$ and $260 \mathrm{~h}^{-1}$, respectively, for runs R1 and R2. However when the gas flow rate was doubled, the maximum apparent $k_{L, C O} a / V_{L}$ increased by $24 \%$ and apparent $k_{L, H 2} a / V_{L}$ decreased by $46 \%$ in runs R3 to R4. It should be noted that the actual $k_{L, H 2} a / V_{L}$ should also increase. However, higher liquid phase $\mathrm{CO}$ concentration inhibits the uptake of $\mathrm{H}_{2}$. The maximum apparent $k_{L, C O} a / V_{L}$ and $k_{L, H 2} a / V_{L}$ increased up to $50 \%$ and $103 \%$, respectively, in runs R7 to R10 compared to R3 due to more cells in the packing. This increase in the apparent mass transfer of $\mathrm{CO}$ and $\mathrm{H}_{2}$ (Fig. 6) at the same operating condition in the subsequent runs from R3 to R10 was associated with an increase in cells' gas uptake (Fig. $5 \mathrm{~A}$ ). When the liquid recirculation rate was increased from $200 \mathrm{ml} / \mathrm{min}$ (R10 and $\mathrm{R} 12)$ to $500 \mathrm{ml} / \mathrm{min}$ (R11 and R13), the maximum apparent $k_{L, C O} a / V_{L}$ and $k_{L, H 2} a / V_{L}$ decreased by $68 \%$ and $49 \%$, respectively. In addition, at $700 \mathrm{ml} / \mathrm{min}$ of liquid recirculation rate (R14 and R15), the maximum apparent $k_{L, C O} a / V_{L}$ and $k_{L, H 2} a / V_{L}$ decreased by $73 \%$ and $54 \%$, respectively, compared to runs $\mathrm{R} 9$ and $\mathrm{R} 10$ at $200 \mathrm{ml} / \mathrm{min}$. The increase in the liquid recirculation rate increased $V_{L}$, the liquid holdup volume (Orgill et al., 2013), which resulted in a decrease in the $k_{L, i} a / V_{L}$ values for both $\mathrm{CO}$ and $\mathrm{H}_{2}$.

The $k_{L, H 2} a / V_{L}$ was also predicted from the apparent $k_{L, C O} a / V_{L}$ using boundary layer theory (Fig. 6B). According to this theory (Sherwood et al., 1975), the mass transfer coefficient and diffusivities of two different chemical species under identical hydrodynamic conditions can be correlated by

$$
\frac{\left(k_{L, i} \cdot a / V_{L}\right)_{i}}{\left(k_{L, i} \cdot a / V_{L}\right)_{j}}=\left(\frac{D_{i}}{D_{j}}\right)^{1 / 2}
$$


where, $\left(k_{L, i} a / V_{L}\right)_{\mathrm{i}}$ and $\left(k_{L, i} a / V_{L}\right)_{\mathrm{j}}$ are the mass transfer coefficients of the $i$ and $j$ gases, respectively, and $D_{i}$ and $D_{j}$ are diffusivities for the $i$ and $j$ gases, respectively. The diffusivities of $\mathrm{CO}$ and $\mathrm{H}_{2}$ at $37{ }^{\circ} \mathrm{C}$ are $3.26 \times 10^{-9}$ and $6.48 \times 10^{-9} \mathrm{~m}^{2} / \mathrm{s}$, respectively (Verhallen et al., 1984; Wise and Houghton, 1968). The predicted $k_{L, H 2} a / V_{L}$ (dashed lines) using the boundary layer theory based on CO data were much higher than the apparent $k_{L, H_{2}} a / V_{L}$ calculated from the experimental $\mathrm{H}_{2}$ consumption data (Fig. 6B). This clearly indicates that the capability of the TBR to transfer $\mathrm{H}_{2}$ into the medium was not fully utilized due to the cells' kinetic limitation associated with inhibition of hydrogenase activity by CO (Skidmore, 2010). The apparent $k_{L, C O} a / V_{L}$ has a decreasing trend with increasing liquid flow rate as shown in pure mass transfer experiments (Orgill et al., 2013). However, the apparent $k_{L, C O} a / V_{L}$ obtained in fermentation experiments are at least tenfold higher than that observed in the pure mass transfer experiments with air-water system (Orgill et al., 2013). The results showed that repetitive semi-continuous fermentations in the TBR with medium replenishment increased amount of cells in the packing and fermentation activity. In addition, the TBR operation in the co-current mode was simpler, avoided flooding issues and resulted in more ethanol production than in counter-current flow. The use of packing materials with larger void volume such as Pall rings in the TBR and increase in gas flow rate in co-current mode have the potential to increase mass transfer, gas conversion efficiency and ethanol titers, which warrant further investigation.

\section{Conclusions}

Increased amount of cells in the packing and possible biofilm formation in the TBR reduced $\mathrm{CO}$ inhibition and improved $\mathrm{H}_{2}$ conversion and uptake by 1.9 times at $4.6 \mathrm{sccm}$ of gas flow and $200 \mathrm{ml} / \mathrm{min}$ of liquid recirculation rate. At the end of the experiment at 1662 
$\mathrm{h}, 12.3 \mathrm{~g} / \mathrm{L}$ of acetic acid and $5.7 \mathrm{~g} / \mathrm{L}$ of ethanol were produced. Acetic acid production rates were higher than ethanol due to the repeated replenishment of nutrients, which provided growth supporting environment. Operating the TBR in co-current mode reduced the gas bypass and TBR flooding issues that were encountered in counter-current operation.

\section{Acknowledgments}

This research was supported by a grant from the Sun Grant Initiative through the U.S. Department of Transportation, USDA-NIFA Project No. OKL03005 and Oklahoma Agricultural Experiment Station.

\section{References}

1. Abubackar, H.N., Veiga, M.C., Kennes, C. 2015. Carbon monoxide fermentation to ethanol by Clostridium autoethanogenum in a bioreactor with no accumulation of acetic acid. Bioresour. Technol., 186, 122-127.

2. Bredwell, M.D., Srivastava, P., Worden, R.M. 1999. Reactor Design Issues for Synthesis-Gas Fermentations. Biotechnol. Prog., 15, 834-844.

3. Cotter, J.L., Chinn, M.S., Grunden, A.M. 2009. Influence of process parameters on growth of Clostridium ljungdahlii and Clostridium autoethanogenum on synthesis gas. Enzyme Microb. Technol., 44, 281-288.

4. Cowger, J.P., Klasson, K.T., Ackerson, M.D., Clausen, E., Caddy, J.L. 1992. Masstransfer and kinetic aspects in continuous bioreactors using Rhodospirillum rubrum. Appl. Biochem. Biotechnol., 34-35, 613-624.

5. Garcia-Ochoa, F., Gomez, E. 2009. Bioreactor scale-up and oxygen transfer rate in microbial processes: an overview. Biotechnol. Adv., 27, 153-176.

6. Hu, P., Bowen, S.H., Lewis, R.S. (2011). A thermodynamic analysis of electron production during syngas fermentation. Bioresour. Technol.,102, 8071-8076.

7. Huhnke, R.L., Lewis, R.S., Tanner, R.S., 2010. Isolation and Characterization of Novel Clostridial Species. US Patent No. 7704,723. 
8. Kimmel, D.E., Klasson, K.T., Clausen, E.C., Gaddy, J.L. 1991. Performance of tricklebed bioreactors for converting synthesis gas to methane. Appl. Biochem. Biotechnol., 28-29, 457-469.

9. Klasson, K., Ackerson, M., Clausen, E., Gaddy, J. 1991. Bioreactors for synthesis gas fermentations. Resour. Conserv. Recycl., 5, 145-165.

10. Klasson, K., Cowger, J., Ko, C., Vega, J., Clausen, E., Gaddy, J. 1990a. Methane production from synthesis gas using a mixed culture of R. rubrum, M. barkeri, and M. formicicum. Appl. Biochem. Biotechnol., 24, 317-328.

11. Klasson, K., Elmore, B., Vega, J., Ackerson, M., Clausen, E., Gaddy, J. 1990 b. Biological production of liquid and gaseous fuels from synthesis gas. Appl. Biochem. Biotechnol., 24, 857-873.

12. Klasson, K.T., Ackerson, M.D., Clausen, E.C., Gaddy, J.L. 1992. Bioconversion of synthesis gas into liquid or gaseous fuels. Enzyme Microb. Technol., 14, 602-608.

13. Klasson, T.K., Ackerson, M.D., Clausen, E.C., Gaddy, J.L. 1993. Biological conversion of coal and coal-derived synthesis gas. Fuel, 72, 1673-1678.

14. Liu, K., Atiyeh, H.K., Stevenson, B.S., Tanner, R.S., Wilkins, M.R., Huhnke, R.L. 2014a. Continuous syngas fermentation for the production of ethanol, n-propanol and nbutanol. Bioresour. Technol., 151, 69-77.

15. Liu, K., Atiyeh, H.K., Stevenson, B.S., Tanner, R.S., Wilkins, M.R., Huhnke, R.L. 2014b. Mixed culture syngas fermentation and conversion of carboxylic acids into alcohols. Bioresour. Technol., 152, 337-346.

16. Liu, K., Atiyeh, H.K., Tanner, R.S., Wilkins, M.R., Huhnke, R.L. 2012. Fermentative production of ethanol from syngas using novel moderately alkaliphilic strains of Alkalibaculum bacchi. Bioresour. Technol., 104, 336-341.

17. Maddipati, P., Atiyeh, H.K., Bellmer, D.D., Huhnke, R.L. 2011. Ethanol production from syngas by Clostridium strain P11 using corn steep liquor as a nutrient replacement to yeast extract. Bioresour. Technol., 102, 6494-6501.

18. Orgill, J.J., Atiyeh, H.K., Devarapalli, M., Phillips, J.R., Lewis, R.S., Huhnke, R.L. 
2013. A comparison of mass transfer coefficients between trickle-bed, hollow fiber membrane and stirred tank reactors. Bioresour. Technol., 133, 340-346.

19. Phillips, J.R., Clausen, E.C., Gaddy, J.L. 1994. Synthesis gas as substrate for the biological production of fuels and chemicals. Appl. Biochem. Biotechnol., 45, 145-157.

20. Po, H.N., Senozan, N. 2001. The Henderson-Hasselbalch equation: Its history and limitations. J. Chem. Educ., 78, 1499-1503.

21. Ranade, V.V., Chaudhari, R., Gunjal, P.R. 2011. Trickle Bed Reactors: Reactor Engineering \& Applications. ${ }^{\text {st }}$ ed. Elsevier Science Limited, Kidlington, Oxford, pp.284.

22. Saroha, A., Nigam, K. 1996. Trickle bed reactors. Rev. Chem. Eng., 12, 207-347.

23. Shen, Y., Brown, R., Wen, Z. 2014. Syngas fermentation of Clostridium carboxidivoran $\mathrm{P} 7$ in a hollow fiber membrane biofilm reactor: Evaluating the mass transfer coefficient and ethanol production performance. Biochem. Eng. J., 85, 21-29.

24. Sherwood, T.K., Pigford, R.L., Wilke, C.R. 1975. Mass transfer. McGraw-Hill Inc., New York, pp.512.

25. Singla, A., Verma, D., Lal, B., Sarma, P.M. 2014. Enrichment and optimization of anaerobic bacterial mixed culture for conversion of syngas to ethanol. Bioresour. Technol., 172, 41-49.

26. Skidmore, B.E. 2010. Syngas Fermentation: Quantification of assay technoques, reaction kinetics and pressure dependencies of the Clostridium P11 hydrogenase. MS Thesis. Bringham Young University, 136.

27. Ukpong, M.N., Atiyeh, H.K., De Lorme, M.J., Liu, K., Zhu, X., Tanner, R.S., Wilkins, M.R., Stevenson, B.S. 2012. Physiological response of Clostridium carboxidivorans during conversion of synthesis gas to solvents in a gas-fed bioreactor. Biotechnol. Bioeng., 109, 2720-2728.

28. Vega, J.L., Clausen, E.C., Gaddy, J.L. 1990. Design of bioreactors for coal synthesis gas fermentations. Resour. Conserv. Recycl., 3, 149-160.

29. Verhallen, P., Oomen, L., Elsen, A., Kruger, J., Fortuin, J. 1984. The diffusion 
coefficients of helium, hydrogen, oxygen and nitrogen in water determined from the permeability of a stagnant liquid layer in the quasi-s. Chem. Eng. Sci., 39, 1535-1541.

30. Wise, D., Houghton, G. 1968. Diffusion coefficients of neon, krypton, xenon, carbon monoxide and nitric oxide in water at 10-60 C. Chem. Eng. Sci., 23, 1211-1216.

31. Wolfrum, E.J., Watt, A.S. 2002. Bioreactor design studies for a hydrogen-producing bacterium. Appl. Biochem. Biotechnol., 98, 611-625.

32. Wood, H.G., Ragsdale, S.W., Pezacka, E. 1986. The acetyl-CoA pathway of autotrophic growth. FEMS Microbiol. Lett., 39, 345-362.

33. Younesi, H., Najafpour, G., Mohamed, A.R. 2005. Ethanol and acetate production from synthesis gas via fermentation processes using anaerobic bacterium, Clostridium ljungdahlii. Biochem. Eng. J., 27, 110-119.

34. Zahn, J. A., Saxena, J. 2014. Ethanologenic Clostridium species, Colstriduim coskatii. U.S. Patent No. 8,802,405. 


\section{Figure Captions}

Fig. 1. TBR Semi-continuous fermentation setup. (1) Nitrogen cylinder, (2) Syngas cylinder, (3) Rotameter, (4) Trickle bed reactor, (5) Medium sump, (6) ORP probe, (7) pH probe, (8) Masterflex pump, (9) Liquid sampling port, (10) Acid/base addition, (11) Pressure gauge, (12) Gas sampling port, (13) By pass line with solenoid valve and pressure switch, (14) Back pressure regulator, (15) Gas bubbler, (16) $108 \mathrm{kPa}$ check valve, and (17) Ball valve.

Fig. 2. Cell mass optical density $\left(\mathrm{OD}_{660}\right)$ profiles of $C$. ragsdalei during semi-continuous syngas fermentations in TBR: selected runs ( $\bullet) \mathrm{R} 1,(\Delta) \mathrm{R} 2,(\times) \mathrm{R} 3,(*) \mathrm{R} 4,(\diamond) \mathrm{R} 7,(\Delta)$ R9, ( $)$ R10, ( $\square) \mathrm{R} 11,(*) \mathrm{R} 14,(\bullet) \mathrm{R} 15,(+) \mathrm{R} 17,(-) \mathrm{R} 18$ and, ( $\square)$ R19. Runs R1 \& R2: $\mathrm{L}=200 \mathrm{ml} / \mathrm{min}, \mathrm{G}=2.3 \mathrm{sccm}$; $\mathrm{R} 4$ to $\mathrm{R} 9$ and $\mathrm{R} 19: \mathrm{L}=200 \mathrm{ml} / \mathrm{min}, \mathrm{G}=4.6 \mathrm{sccm}$; $\mathrm{R} 11$ \& $\mathrm{R} 17: \mathrm{L}=500 \mathrm{ml} / \mathrm{min}, \mathrm{G}=4.6 \mathrm{sccm}$; R14, R15 \& R18: $\mathrm{L}=700 \mathrm{ml} / \mathrm{min}, \mathrm{G}=4.6 \mathrm{sccm}$. Runs R1 to R15: counter-current mode; R17 to R19: co-current mode.

Fig. 3. (A) Ethanol (B) Acetic acid profiles during semi-continuous syngas fermentations in TBR: selected runs ( $\square) \mathrm{R} 1,(\Delta) \mathrm{R} 2,(\times) \mathrm{R} 3,(*) \mathrm{R} 4,(\diamond) \mathrm{R} 7,(\Delta) \mathrm{R} 9,(\circ) \mathrm{R} 10,(\square) \mathrm{R} 11,($ *) R14, (•) R15, (+) R17, (-) R18 and, ( $\square) \mathrm{R} 19$. Runs R1 \& R2: L = $200 \mathrm{ml} / \mathrm{min}, \mathrm{G}=$ $2.3 \mathrm{sccm}$; $\mathrm{R} 4$ to $\mathrm{R} 9$ and $\mathrm{R} 19: \mathrm{L}=200 \mathrm{ml} / \mathrm{min}, \mathrm{G}=4.6 \mathrm{sccm}$; $\mathrm{R} 11 \& \mathrm{R} 17: \mathrm{L}=500 \mathrm{ml} / \mathrm{min}$, $\mathrm{G}=4.6 \mathrm{sccm}$; R14, R15 \& R18: $\mathrm{L}=700 \mathrm{ml} / \mathrm{min}, \mathrm{G}=4.6 \mathrm{sccm}$. Runs R1 to R15: countercurrent mode; R17 to R19: co-current mode.

Fig. 4. (A) $\mathrm{CO}$ and (B) $\mathrm{H}_{2}$ conversion efficiencies during semi-continuous syngas fermentations in TBR: selected runs $(\square) \mathrm{R} 1,(\Delta) \mathrm{R} 2,(\times) \mathrm{R} 3,(*) \mathrm{R} 4,(\diamond) \mathrm{R} 7,(\Delta) \mathrm{R} 9,(\circ)$ R10, ( $\square) \mathrm{R} 11,(*) \mathrm{R} 14,(\bullet) \mathrm{R} 15,(+) \mathrm{R} 17,(-) \mathrm{R} 18$ and, ( $\square) \mathrm{R} 19$. Runs R1 \& R2: L $=200$ $\mathrm{ml} / \mathrm{min}, \mathrm{G}=2.3 \mathrm{sccm}$; $\mathrm{R} 4$ to $\mathrm{R} 9$ and $\mathrm{R} 19: \mathrm{L}=200 \mathrm{ml} / \mathrm{min}, \mathrm{G}=4.6 \mathrm{sccm}$; $\mathrm{R} 11$ \& $\mathrm{R} 17: \mathrm{L}=$ $500 \mathrm{ml} / \mathrm{min}, \mathrm{G}=4.6 \mathrm{sccm}$; R14, R15 \& R18: L= $700 \mathrm{ml} / \mathrm{min}, \mathrm{G}=4.6 \mathrm{sccm}$. Runs R1 to R15: counter-current mode; R17 to R19: co-current mode.

Fig. 5. (A) Gas uptake rate and (B) product formation rate during semi-continuous syngas fermentations runs (Table 1) in TBR: $(\diamond) \mathrm{CO},(\Delta) \mathrm{H}_{2},(\boldsymbol{\bullet})$ Ethanol and, (•) Acetic acid.

Fig. 6. (A) Apparent $k_{L, C O} a / V_{\mathrm{L}}$ (B) Apparent $k_{L, H 2} a / V_{L}$ assuming mass transfer limitation during semi-continuous syngas fermentations in TBR: selected runs $(\boldsymbol{\square}) \mathrm{R} 1,(\Delta) \mathrm{R} 2,(\times)$ R3, (*) R4, (•) R7, ( $\Delta) \mathrm{R} 9,(\circ) \mathrm{R} 10,(\square) \mathrm{R} 11,(*) \mathrm{R} 14,(\bullet) \mathrm{R} 15,(+) \mathrm{R} 17,(-) \mathrm{R} 18$ and, ( $\square$ ) R19. Runs R1 \& R2: $L=200 \mathrm{ml} / \mathrm{min}, \mathrm{G}=2.3 \mathrm{sccm}$; R4 to R9 and R19: $\mathrm{L}=200$ $\mathrm{ml} / \mathrm{min}, \mathrm{G}=4.6 \mathrm{sccm}$; R11 \& R17: L= $500 \mathrm{ml} / \mathrm{min}, \mathrm{G}=4.6 \mathrm{sccm}$; R14, R15 \& R18: L = $700 \mathrm{ml} / \mathrm{min}, \mathrm{G}=4.6 \mathrm{sccm}$. Runs R1 to R15: counter-current mode; R17 to R19: co-current mode. (---) Predicted $k_{L, H 2} a / V_{L}$ using boundary layer theory. 


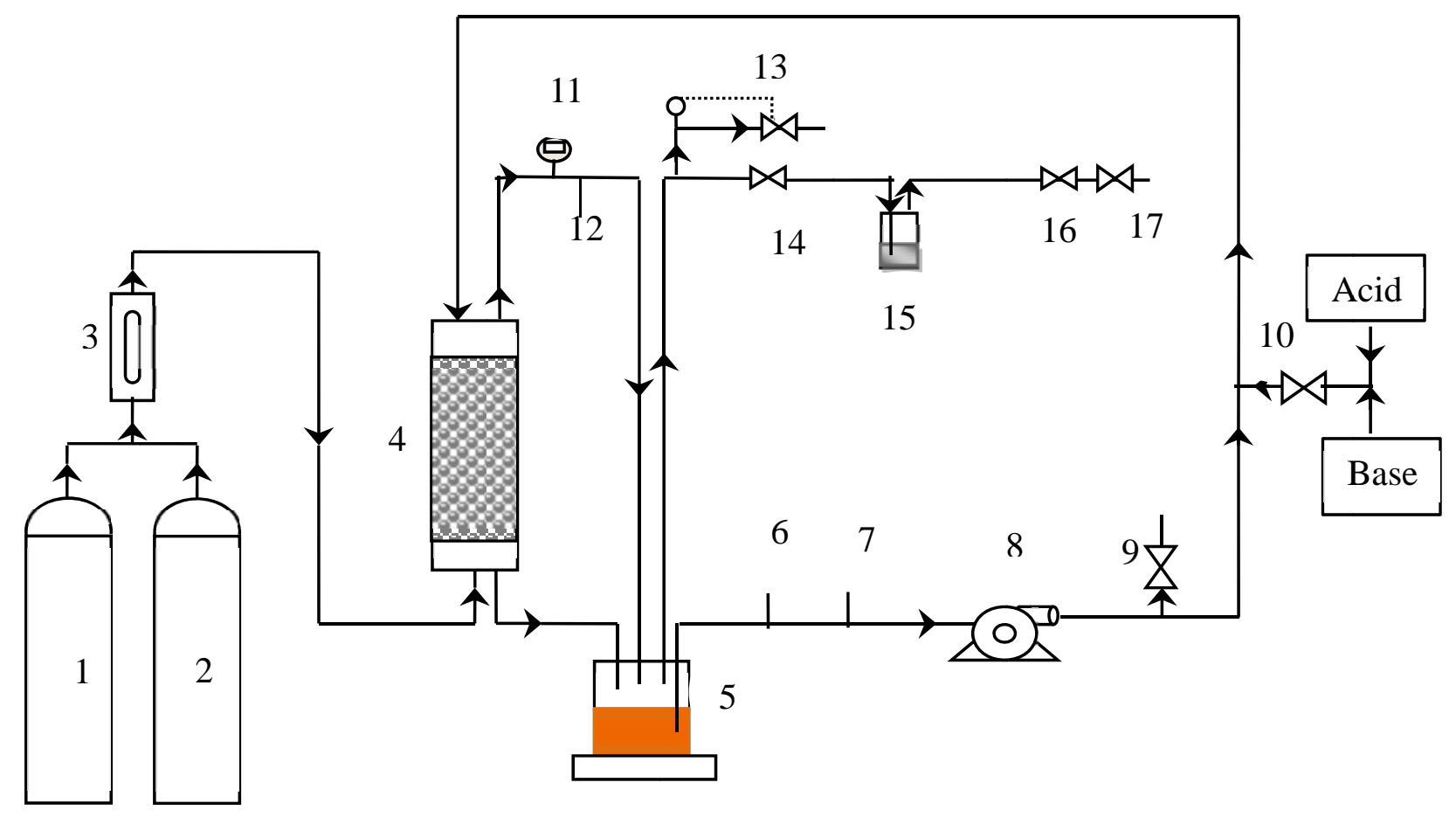

Fig. 1 (Devarapalli et al.) 


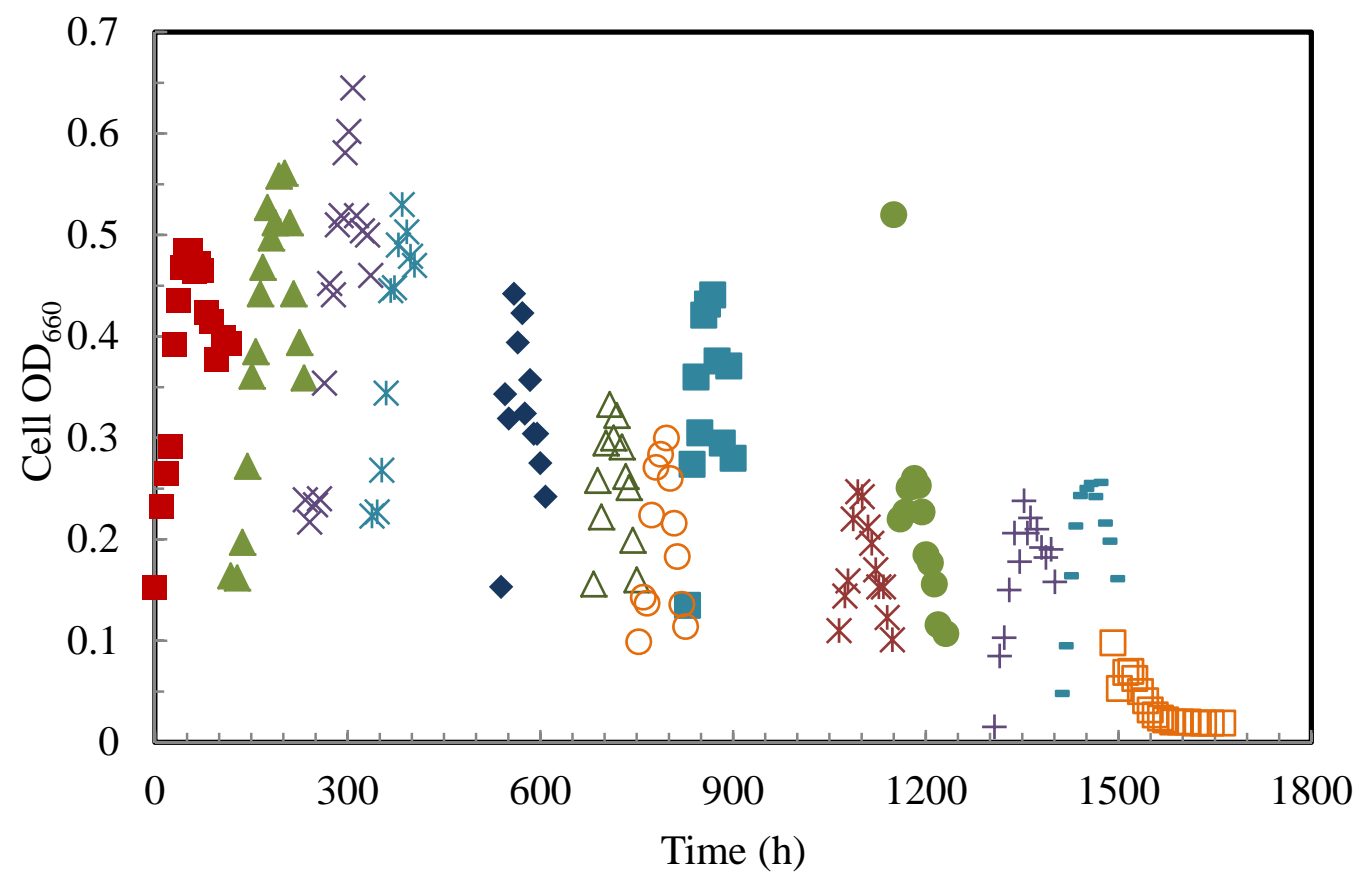

Fig. 2 (Devarapalli et al.) 

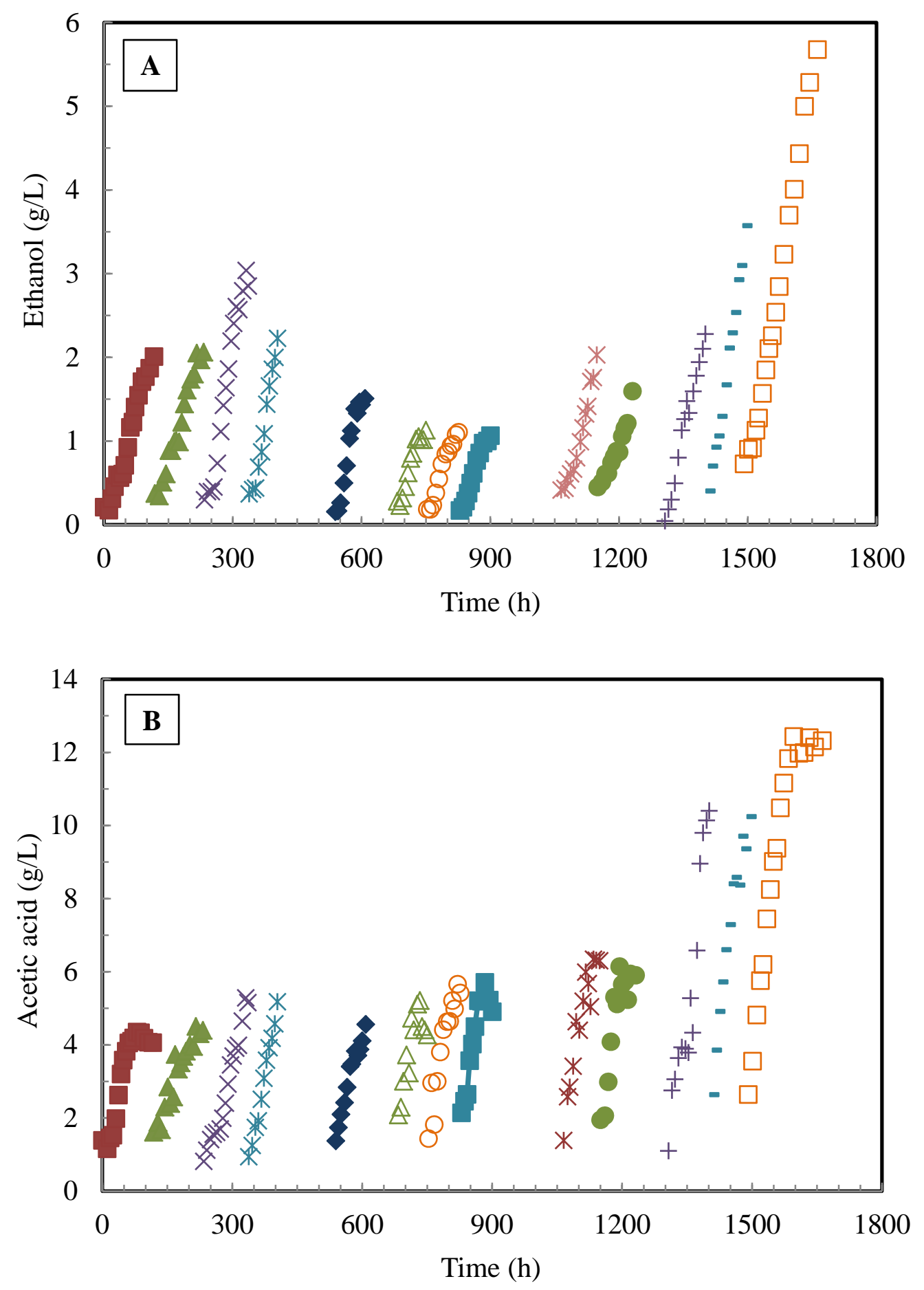

Fig. 3 (Devarapalli et al.) 

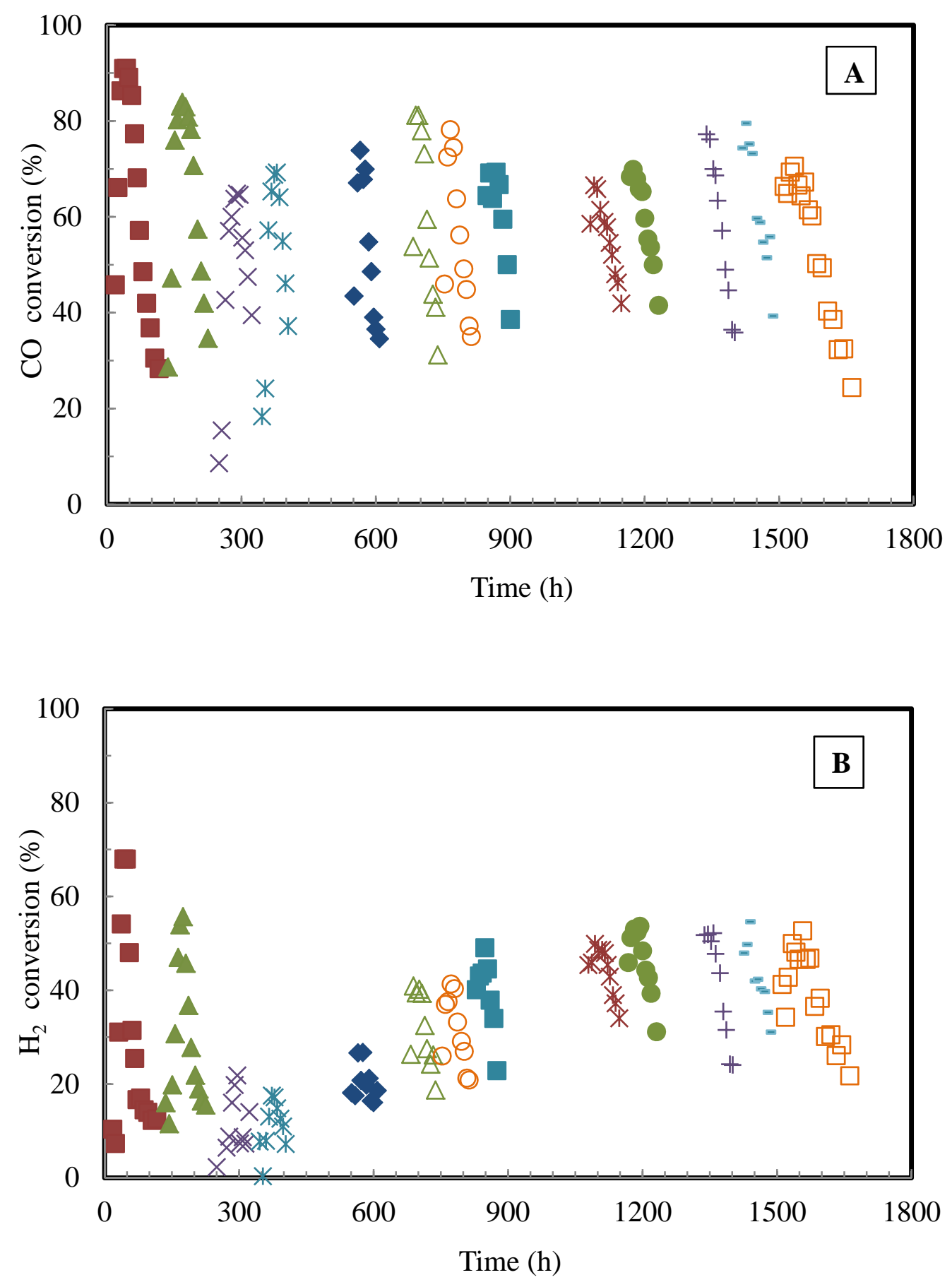

Fig. 4 (Devarapalli et al.) 

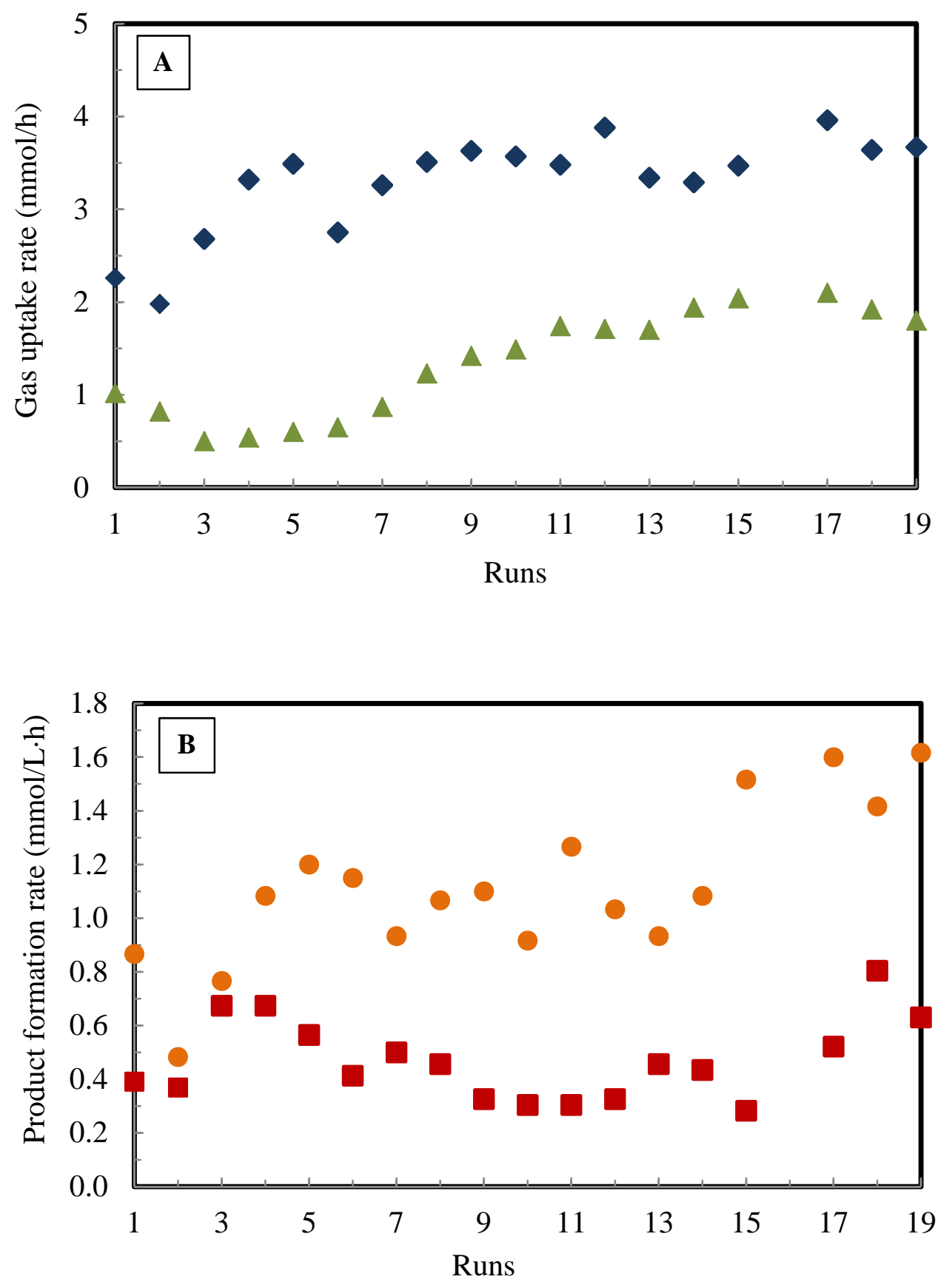

Fig. 5 (Devarapalli et al.) 

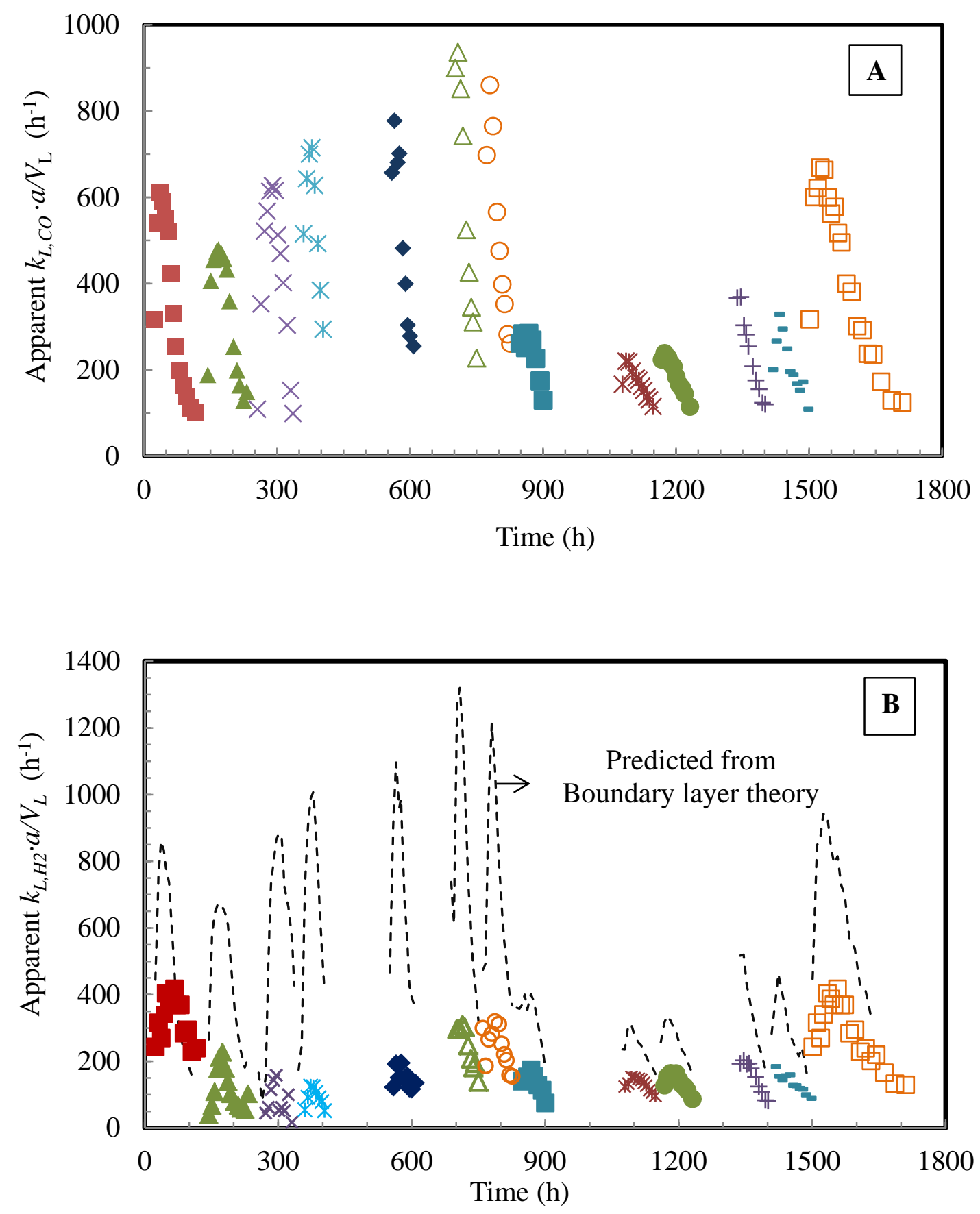

Fig. 6 (Devarapalli et al.) 
Table 1. Ethanol and acetic acid concentrations and yields, and gas conversion efficiencies during semi-continuous syngas fermentations in TBR for runs R1 to R19 in the TBR.

\begin{tabular}{|c|c|c|c|c|c|c|c|c|}
\hline $\operatorname{Run}^{\mathrm{a}}$ & $\begin{array}{c}\text { Time range } \\
\text { (h) }\end{array}$ & $\begin{array}{c}\text { Liquid - Gas } \\
\text { flow rates } \\
(\mathrm{ml} / \mathrm{min})-\mathrm{sccm}\end{array}$ & $\begin{array}{c}\text { Ethanol }^{b} \\
(\mathrm{~g} / \mathrm{L})\end{array}$ & 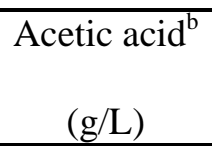 & $\begin{array}{c}\text { Max CO } \\
\text { conversion } \\
\%\end{array}$ & $\begin{array}{c}\text { Max } \mathrm{H}_{2}, \\
\text { conversion } \\
\%\end{array}$ & $\begin{array}{c}\text { Ethanol } \\
\text { yield }^{\mathrm{c}} \\
\%\end{array}$ & $\begin{array}{c}\text { Acetic acid } \\
\text { yield }^{\mathrm{c}} \\
\%\end{array}$ \\
\hline 1 & $0-116$ & $200-2.3$ & 1.16 & 4.06 & 90.97 & 67.99 & 60.93 & 92.83 \\
\hline 2 & $118-232$ & $200-2.3$ & 1.22 & 3.51 & 83.15 & 55.70 & 58.69 & 56.79 \\
\hline 3 & $234-336$ & $200-4.6$ & 2.19 & 3.45 & 64.61 & 21.83 & 91.60 & 61.84 \\
\hline 4 & $338-404$ & $200-4.6$ & 2.00 & 4.58 & 69.25 & 17.54 & 66.72 & 73.27 \\
\hline 5 & $407-477$ & $200-4.6$ & 1.77 & 5.98 & 66.54 & 18.68 & 59.00 & 100.81 \\
\hline 6 & $479-537$ & $200-4.6$ & 1.20 & 5.65 & 66.46 & 19.66 & 42.00 & 93.61 \\
\hline 7 & $539-608$ & $200-4.6$ & 1.43 & 4.11 & 73.89 & 26.65 & 46.70 & 45.49 \\
\hline 8 & $610-681$ & $200-4.6$ & 1.33 & 4.79 & 79.27 & 37.73 & 37.69 & 54.39 \\
\hline 9 & $683-750$ & $200-4.6$ & 1.02 & 4.41 & 81.21 & 40.91 & 26.87 & 37.66 \\
\hline 10 & $753-826$ & $200-4.6$ & 0.96 & 4.99 & 78.2 & 41.36 & 27.99 & 37.92 \\
\hline 11 & $829-900$ & $500-4.6$ & 1.00 & 5.23 & 69.32 & 49.06 & 25.99 & 48.78 \\
\hline 12 & $903-979$ & $200-4.6$ & 1.19 & 4.84 & 76.95 & 46.81 & 30.10 & 52.06 \\
\hline 13 & $981-1063$ & $500-4.6$ & 1.35 & 5.79 & 66.69 & 48.13 & 41.13 & 53.18 \\
\hline 14 & $1065-1148$ & $700-4.6$ & 1.41 & 5.04 & 66.59 & 49.89 & 36.06 & 47.25 \\
\hline 15 & $1150-1231$ & $700-4.6$ & 1.15 & 5.23 & 69.92 & 53.66 & 22.29 & 57.40 \\
\hline 17 & $1307-1401$ & $500-4.6$ & 1.34 & 4.33 & 77.26 & 52.17 & 40.85 & 26.12 \\
\hline 18 & $1403-1489$ & $700-4.6$ & 2.53 & 8.37 & 79.53 & 54.60 & 60.26 & 67.48 \\
\hline 19 & $1491-1662$ & $200-4.6$ & 2.10 & 9.02 & 70.60 & 52.68 & 45.63 & 108.11 \\
\hline
\end{tabular}

${ }^{a}$ R1-R15: counter-current mode; R16: had leak issues, which resulted in no data; R17-19: co-current mode

${ }^{\mathrm{b}}$ Amount of products produced at $60 \pm 4 \mathrm{~h}$ relative to the start of each run

${ }^{\mathrm{c}}$ Yields were calculated based on $\mathrm{CO}$ consumed between $10 \pm 5 \mathrm{~h}$ and $60 \pm 4 \mathrm{~h}$ for each run 
Table 2. Products formed via semi-continuous syngas fermentations in various reactors.

\begin{tabular}{|c|c|c|c|c|}
\hline \multirow{2}{*}{\begin{tabular}{l}
\multicolumn{1}{c}{ Reactor type } \\
Trickled bed (TBR) co- \\
current mode
\end{tabular}} & \multirow{3}{*}{$\begin{array}{c}\text { Microorganisms } \\
\text { Clostridium ragsdalei }\end{array}$} & \multirow{3}{*}{$\begin{array}{l}\text { Operating conditions } \\
\text { YE }^{\mathrm{a}} \text { medium; } \mathrm{pH}: 4.6\end{array}$} & \multirow{2}{*}{$\begin{array}{l}\text { Products }(\mathrm{g} / \mathrm{L}) \\
\text { Ethanol: } 5.7 \\
\text { Acetic acid: } 12.3\end{array}$} & \multirow{3}{*}{$\begin{array}{l}\text { Reference } \\
\text { (This study) }\end{array}$} \\
\hline & & & & \\
\hline $\begin{array}{l}\text { TBR: counter-current } \\
\text { mode }\end{array}$ & & & $\begin{array}{l}\text { Ethanol: } 3.0 \\
\text { Acetic acid: } 5.3\end{array}$ & \\
\hline \multirow[t]{6}{*}{ Stirred tank (STR) } & Clostridium ragsdalei & $\begin{array}{l}\text { YE }{ }^{\mathrm{a}} \text { medium; no } \mathrm{pH} \\
\text { control } \\
\text { CSL medium }{ }^{\mathrm{b}} \text {; no } \mathrm{pH} \\
\text { control }\end{array}$ & $\begin{array}{l}\text { Ethanol: } 5.0 \\
\text { Acetic acid: } 1.5 \\
\text { Ethanol: } 9.6 \\
\text { Acetic acid: } 6.1\end{array}$ & (Maddipati et al., 2011) \\
\hline & Clostridium ljungdahlii & Basal medium; pH: 5.5 & $\begin{array}{l}\text { Ethanol: } 0.2 \\
\text { Acetic acid: } 2.2\end{array}$ & (Cotter et al., 2009) \\
\hline & Clostridium carboxidivorans & $\begin{array}{l}\mathrm{YE}^{\mathrm{a}} \text { medium; no } \mathrm{pH} \\
\text { control }\end{array}$ & $\begin{array}{l}\text { Ethanol: } 1.9 \\
\text { Acetic acid: } 0.3\end{array}$ & (Ukpong et al., 2012) \\
\hline & $\begin{array}{l}\text { Mixed culture of } \\
\text { Alkalibaculum bacchi and } \\
\text { Clostridium propionicum }\end{array}$ & CSL medium ${ }^{\mathrm{b}}, \mathrm{pH}: 6.1$ & $\begin{array}{l}\text { Ethanol: } 1.1 \\
\text { Acetic acid: } 5.9 \\
\text { Propanol: } 1.0 \\
\text { Propionic acid: } 1.5 \\
\text { Butanol: } 0.1 \\
\text { Butyric acid: } 0.4\end{array}$ & (Liu et al., 2014b) \\
\hline & Enriched anaerobic culture & $\begin{array}{l}\mathrm{PBM}^{\mathrm{c}} \text { medium; } \\
\text { No } \mathrm{pH} \text { control }\end{array}$ & $\begin{array}{l}\text { Ethanol: } 2.2 \\
\text { Acetic acid: } 0.9\end{array}$ & (Singla et al., 2014) \\
\hline & $\begin{array}{l}\text { Clostridium } \\
\text { autoethanogenum }\end{array}$ & $\begin{array}{l}\text { Modified mineral } \\
\text { medium; } \mathrm{pH}: 4.75\end{array}$ & $\begin{array}{l}\text { Ethanol: } 0.9 \\
\text { Acetic acid: } 0.0 \\
\text { 2,3 butanediol: } 0.05\end{array}$ & (Abubackar et al., 2015) \\
\hline $\begin{array}{l}\text { Hollow fiber membrane- } \\
\text { Stirred tank (HFR) }\end{array}$ & Clostridium carboxidivorans & $\begin{array}{l}\text { YE and fructose medium; } \\
\mathrm{pH} 4.5-5.5\end{array}$ & $\begin{array}{l}\text { Ethanol: } 15.0 \\
\text { Acetic acid: } 6.0\end{array}$ & (Shen et al., 2014) \\
\hline
\end{tabular}

${ }^{\mathrm{a}}$ YE: Yeast extract; ${ }^{b} \mathrm{CSL}$ : Corn steep liquor; ${ }^{\mathrm{c}}$ PBM: Pfennig's basal medium 